\title{
LATE PLEISTOCENE AND HOLOCENE PALEOENVIRONMENTS IN PONDS AND ALLUVIAL SEDIMENTS OF UPPER PARANÁ RIVER, BRAZIL
}

\author{
RENATO LADA GUERREIRO \\ Instituto Federal de Educação, Ciência e Tecnologia do Paraná, Av. Cívica, 475, 85935-000, Assis Chateaubriand, PR, Brasil. \\ renato.guerreiro@ifpr.edu.br \\ JOSÉ CÂNDIDO STEVAUX \\ Grupo de Estudos Multidisciplinares do Ambiente, UEM, Av. Colombo, 5790, 87020-900, Maringá, PR, Brasil. \\ jcstevaux@uem.br \\ MAURO PAROLIN \\ Laboratório de Estudo Paleoambientais da FECILCAM, Rua Chafic Bader Maluf, 21, 87300-170, Campo Mourão, PR, Brasil. \\ mauroparolin@gmail.com \\ MARIO LUIS ASSINE \\ Departamento de Geologia Aplicada, UNESP, Av. 24 A,1515, 13506-900, Rio Claro, SP, Brasil. \\ assine@rc.unesp.br
}

\begin{abstract}
Freshwater sponge spicules were analyzed as a paleoenvironmental proxy indicator in five cores of ponds and alluvial fan sediments in the Upper Paraná River's left bank, near Querência do Norte town, northwestern of State of Paraná, southern Brazil. Two optically stimulated luminescence (OSL) dates were obtained from sediments of ponds and one radiocarbon $\left({ }^{14} \mathrm{C}\right)$ date was obtained from the alluvial fan. Microscopic analysis of spicules preserved in the sediments allowed a determination of freshwater sponge species. The species assemblage provides evidence for dominantly dry conditions in the Upper Paraná River during the Late Pleistocene. A wetter climate phase was recognized at ${ }^{14} \mathrm{C} 7,540 \mathrm{yrs} \mathrm{BP}$, with alluvial fan formation commencing at the transition of the dry Pleistocene climate to the Early Holocene wet climate. This wet interval was characterized by a sponge assemblage marked by the presence of the Neotropical families and typically associated with lotic environments. Sponge spicules analysis from pond sediments reject the possibility that lotic environments contributed to pond genesis and evolution.
\end{abstract}

Key words: freshwater sponge spicules, Quaternary, paleoclimate, ponds, alluvial fan, Paraná River.

RESUMO - Foram analisados espículas de esponjas de água doce como indicadores proxy de condições paleoambientais em cinco testemunhos recuperados em lagoas e leque aluvial da margem esquerda do alto rio Paraná, próximo à cidade de Querência do Norte, noroeste do Estado do Paraná, sul do Brasil. Duas datações por luminescência opticamente estimulada (LOE) foram obtidas nos sedimentos lacustres e uma datação ${ }^{14} \mathrm{C}$ em sedimentos do leque aluvial. Com base na determinação específica de esponjas de água doce foi possível evidenciar condições ambientais mais secas que as atuais no alto rio Paraná do Pleistoceno tardio até o inicio do Holoceno. Registra-se a transição de climas secos pleistocênicos para climas úmidos no Holoceno, com a formação de leque aluvial, cujos sedimentos foram datados em ${ }^{14} \mathrm{C} 7.540$ anos AP. Dados de espículas de esponjas nos sedimentos lacustres permitiram descartar a contribuição de ambientes lóticos da gênese e evolução das lagoas.

Palavras-chave: espículas de esponjas de água doce, Quaternário, paleoclima, lagoas, leque aluvial, rio Paraná.

\section{INTRODUCTION}

The Paraná River is South America's second largest river and it forms the main trunk river of the La Plata Basin. The upper course of the Paraná River is located between the headwaters and the beginning of the reservoir of Itaipú Dam (formerly Sete Quedas Falls), near to the Piquiri River mouth on the border of Brazil and Paraguay.

Stevaux (1993) recognized four geomorphologic units along the alluvial valley in the Taquarussu area. Most of those units are on the Paraná River's right bank: (i) Porto Rico Unit, with colluvial deposits and/or pedogenesis of Caiuá Formation sandstones; (ii) Taquaruçu Unit, with alluvial-colluvial deposits and numerous ponds of varying formats similar to those of in the study area; (iii) Fazenda Boa Vista Unit, with depositional geoforms characteristics of braided river system that are partly covered by alluvial fans; and (iv) Paraná River Unit, which forms the modern fluvial plain.

The presence of ponds, some of them interconnected with each other, is a defining geomorphological feature of Taquaruçu unit, particularly well developed on the right bank 
of the Paraná River. Most of these ponds have circular, semicircular and irregular longitudinal shapes.

The first hypothesis related to the genesis of these ponds was attributed to pseudokarstic process (Stevaux, 1994). Other researchers have suggested that the ponds formed through sedimentation of an old drainage network, and filling of abandoned river channels for overflow water (Ferreira, 1997; Ferreira \& Caetano Chang, 2003). Sponge spicule studies carried out by Parolin (2006) showed the absence of lotic processes in the genesis of some ponds. Fontana (2009) attributed their formation to illuviation and hydromorphic hypothesis due to the low terrain slope.

Terrace levels and sedimentary deposits of different ages in the Upper Paraná River have been associated with paleohydrological and paleoenvironmental Quaternary paleoclimatic changes (Stevaux, 1993, 1994). Guerreiro (2011) characterized terrace levels, ponds and alluvial fans on the Paraná River left bank, correlating them with geomorphic units recognized by Stevaux (1993).

According to Volkmer-Ribeiro \& Pauls (2000), freshwater sponges have siliceous skeleton (spicules), comprising: (i) megascleres-spicules that constitutes the skeletal network; usually the largest spicules; (ii) microscleres- whose surface is covered by spines; only some taxa have diagnostic value for determination of genera and/or species; and (iii) gemmoscleres-spicules that cover the sponges' gemmules; the most important morphological character for the identification of families, genera and species .

Usually, each freshwater sponge species needs specific environmental conditions to survive, ranging from lotic to lentic. The identification of spicules in the sedimentary records makes it possible to recognize and interpret environments that occurred in the past (Parolin \& Volkmer-Ribeiro, 2010; McGlue et al., 2012; Kuerten et al., 2013).

The present study was based primarily on proxy records like freshwater sponge spicules, with additional information gained from associated with microfossils such as diatom frustules and phytholiths on cores of the ponds and Juriti alluvial fan.

\section{STUDY AREA}

The study area is located in the northwest of Paraná State along the border with Mato Grosso do Sul State, on the eastern margin of Paraná River, north from the Ivaí River mouth (Figure 1).

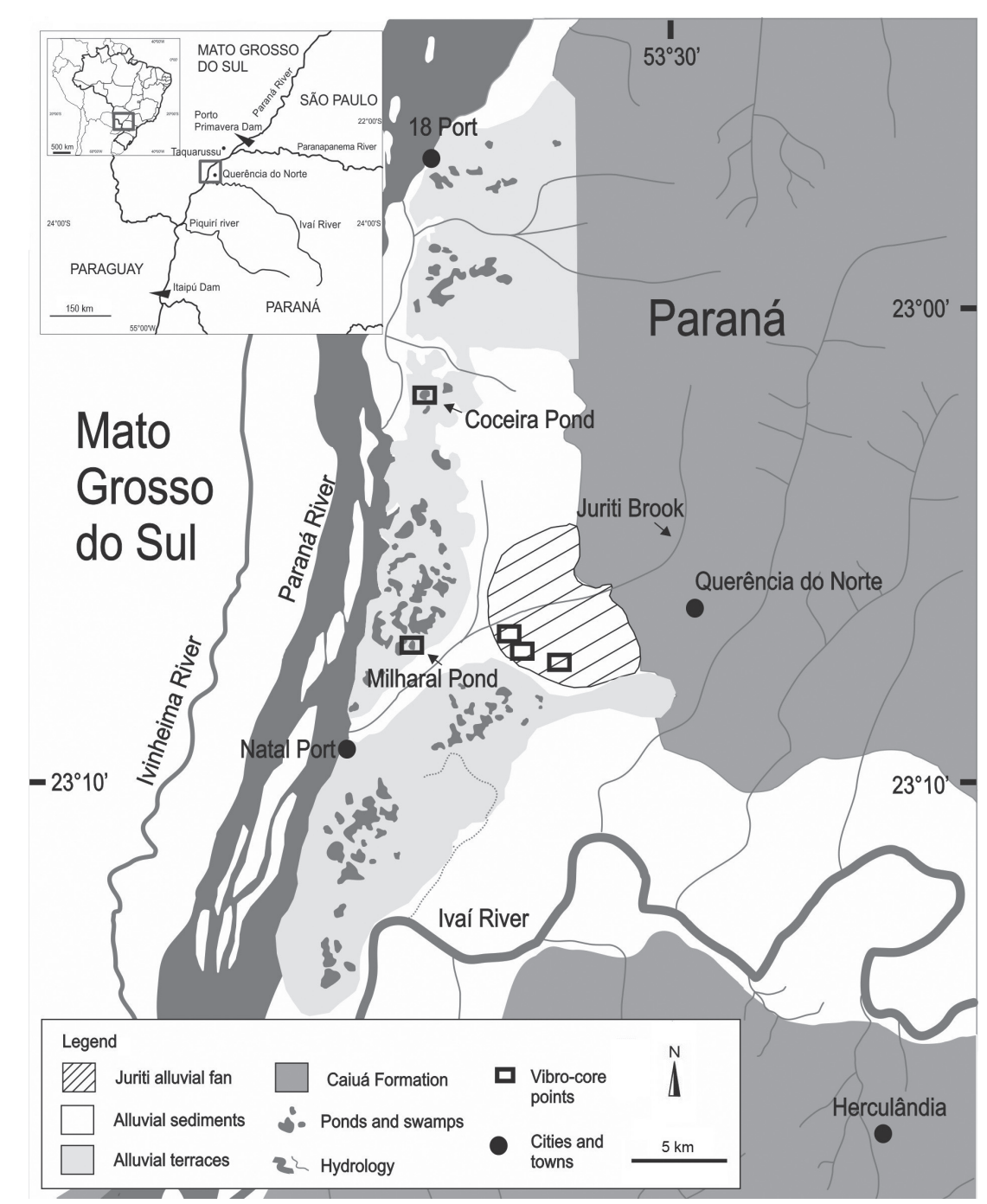

Figure 1. Localization of study area and vibrocoring points at Juriti alluvial fan, Coceira and Milharal ponds. 
The area preserves important geomorphological features such as Quaternary fluvial terraces and plains, similar to those described $60 \mathrm{~km}$ upstream by Stevaux $(1993,1994)$ in the western margin of the Paraná River. Inactive alluvial fans and ponds deposits have preserved important geomorphological and paleoenvironmental records of the evolution of Paraná River plain (Guerreiro, 2011).

The area has a Cfa climate type based on the Köppen classification system (IAPAR, 2012). The climate is best described as humid subtropical, with the highest concentration of rainfall during the summer months and no definite dry season. In the warmer months the average temperatures are above $22^{\circ} \mathrm{C}$ and in the colder months the temperature is below $18^{\circ} \mathrm{C}$. The precipitation average rates are around $1,350 \mathrm{~mm}$ per year (Destefani, 2005).

Originally, the vegetation was composed of semideciduous forest, alluvial semi-deciduous forest and fluvial-lacustrine pioneering formations around the creeks and swampy areas. The high fertility of soils in the region caused the replacement of large areas of forest for agriculture, reducing the original vegetation to small isolated areas scattered in the region, mainly in private reserves.

Besides the presence of terraces and alluvial fans, there are sets of ponds and swamps of many sizes and shapes. The Coceira and Milharal ponds (Figure 1) were analyzed for sediment and micro-palaeontological content. These ponds show shapes ranging between longitudinal irregular and slightly oval, respectively. Both ponds are shallow water (rarely exceeding $60 \mathrm{~cm}$ ) and characterized by dense macrophyte vegetation.

The Juriti alluvial fan (Figure 1) is about $5.5 \mathrm{~km}$ long and exhibits a gentle slope, with altitudes varying between 255 $\mathrm{m}$ in the proximal and $239 \mathrm{~m}$ in distal portion, resulting in a gradient of $2.7 \mathrm{~m} / \mathrm{km}$. The Juriti Stream is approximately $21 \mathrm{~km}$ long and has been diverted to supply several artificial channels and dams for irrigation.

\section{MATERIAL AND METHODS}

Cores were extracted by vibro-coring from two ponds and alluvial sediments. Five cores were processed in total. One sample was forwarded for radiocarbon $\left({ }^{14} \mathrm{C}\right)$ dating to Beta Analytic Lab and two samples to Optically Stimulated Luminescence (OSL) dating in Laboratório de Vidros e Datação of FATEC-São Paulo-SP.

The storage of sediment samples (code S.C.5, 13, 16-18, 29, 38, 43, 47, 49-52), slide collection (code L.5759.C.05; L.60-65,67,68.C.06; L.75,76.C.07; L.161.C.15) and laboratory procedures to develop proxy bioindicators extract was realized in the Laboratório de Estudo Paleoambientais (Lepafe) da FECILCAM at Campo Mourão municipality, Paraná State, Brazil.

Sponge spicules were extracted in portions sampled every $3 \mathrm{~cm}$, boiled in a test tube with nitric acid (65\%) and washed with distilled water and alcohol (70\%), following by centrifugation. The resultant material was dripped on slides and covered with cover slip and Entelan ${ }^{\circledR}$. Diatoms frustules and phytoliths that commonly appeared in the slides were also considered, but without specific identification.

The proxy bioindicators score of was developed based on the absolute number of organisms per slide. For scores between: (i) 1-10 organisms were assigned as very rare occurrence $( \pm)$; (ii) between $11-30$ as rare $(+)$; (iii) between 31-60 as common (++); (iv) over 61 as abundant $(+++)$; (v) 0 as absent $(\varnothing)$. The identification of freshwater sponge spicules was based on the sponge spicules collection of Lepafe and works of Volkmer-Ribeiro \& Parolin (2010). For the identification of phytoliths, the references of Piperno (2006), Honaine et al. (2006), Lu et al. (2007) and Osterrieth et al. (2009) were especially helpful. Diatom frustules were recognized based in Leandrini et al. (2010). The interpretations of limnological and paleolimnological environments of diatoms frustules was based in Stroemer \& Smol (1999) and Wolin \& Durthie (1999).

\section{RESULTS}

Five core samples in ponds at alluvial terrace associated with the Paraná River and the Juriti alluvial fan distal portion were recovered (Figure 2). The geochronology shows that the sediments recovered in the cores span the Late Pleistocene through Holocene periods. Milharal Pond was dated at OSL $20,600 \pm 4,800$ yrs, Coceira Pond dated at OSL 20,600 $\pm 4,800$ yrs, and Juriti alluvial fan dated at ${ }^{14} \mathrm{C} 7,540$ yrs BP (Tables1-3).

Three bioindicators were found in sediments (Tables 1-5) corresponding to five freshwater sponges species, identified by gemmoscleres (Figure 3), corresponding to: (i) Dosilia pydanieli Volkmer-Ribeiro, 1992; (ii) Radiospongilla amazonensis Volkmer-Ribeiro \& Maciel, 1983; (iii) Metania spinata (Carter, 1881); and (iv) Uruguaya corallioides (Bowerbank, 1863) and Trochospongilla repens (Hinde, 1888). The phytoliths forms were identified as trapeziform polylobate, elongate, fan-shaped, bilobate and cross (Figure 3), all representatives of Poaceae and associated subfamilies. Some diatom frustules were found but they did not allow specific identification.

\section{DISCUSSION}

\section{Ponds}

Gemmoscleres identified on Coceira Pond deposits are typical of sponge species from lacustrine environments. The spicules of Dosilia pydanieli at $55-40 \mathrm{~cm}$ indicate a lentic environment, and OSL data at the depth of $44 \mathrm{~cm}$ point out that this pond had already been established $\sim 26,900 \pm 5,000$ yrs BP. Sponge spicules revealed phases with climate conditions drier than today between $40-10 \mathrm{~cm}$, but during this interval the pond was permanent as indicated by abundance of $D$. pydanieli megascleres and Radiospongilla amazonensis gemmoscleras. Gemmoscleres production provides evidence for dry conditions with seasonal oscillations in the average pond water level (Volkmer-Ribeiro et al., 1998).

Dosilia pydanieli microscleres in the sediment at $5 \mathrm{~cm}$ records a low water level fluctuation in the pond (e.g. Parolin, 

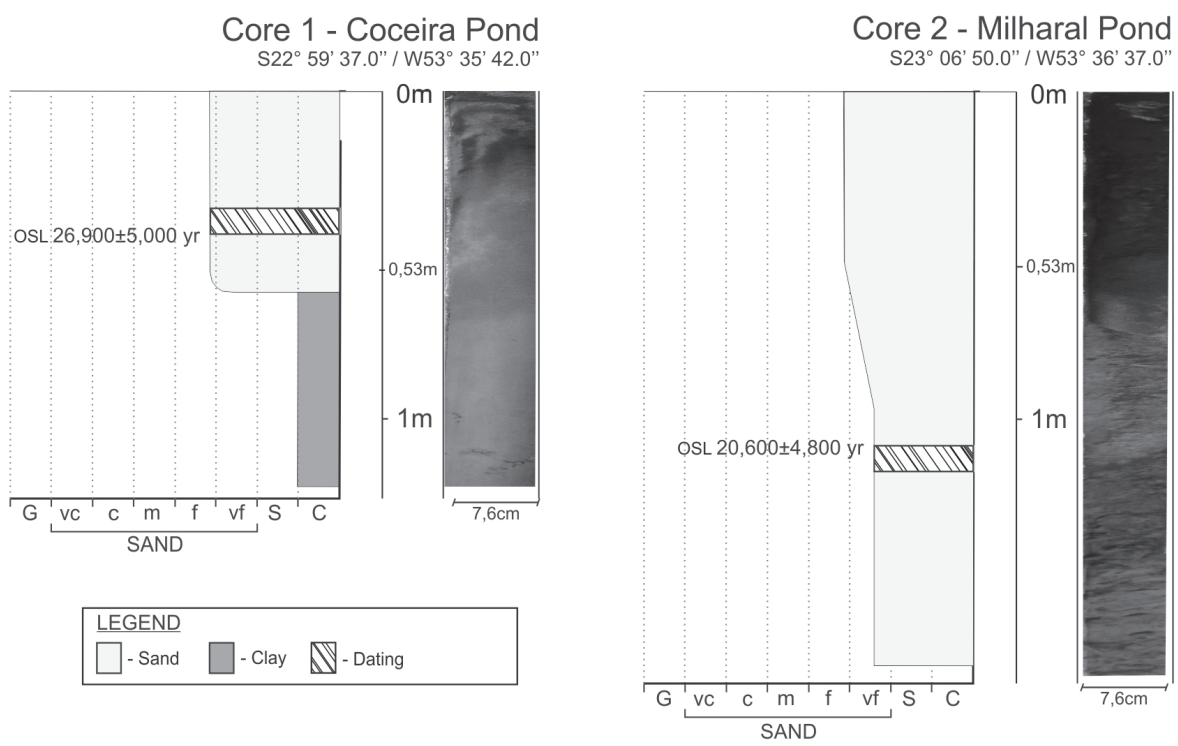

Core 3 - Juriti alluvial fan $\mathrm{S} 23^{\circ} 08^{\prime} 09.0^{\prime \prime} / \mathrm{W} 53^{\circ} 31^{\prime} 37.0^{\prime \prime}$

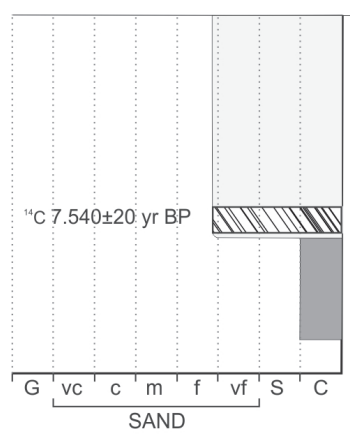

Core 4 - Juriti alluvial fan S23 $08^{\prime} 07.0^{\prime \prime} / \mathrm{W} 53^{\circ} 32^{\prime} 440^{\prime \prime}$

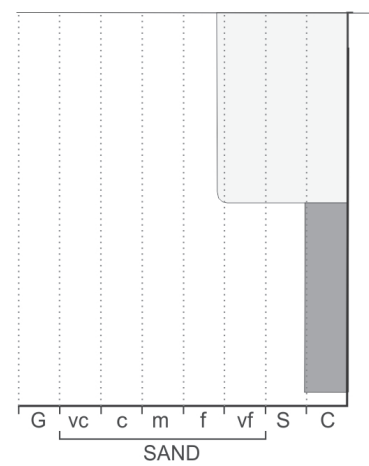

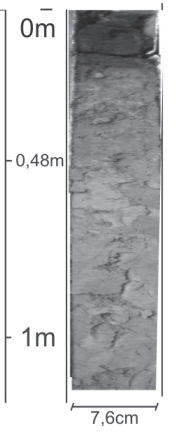

Core 5 - Juriti alluvial fan

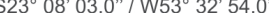

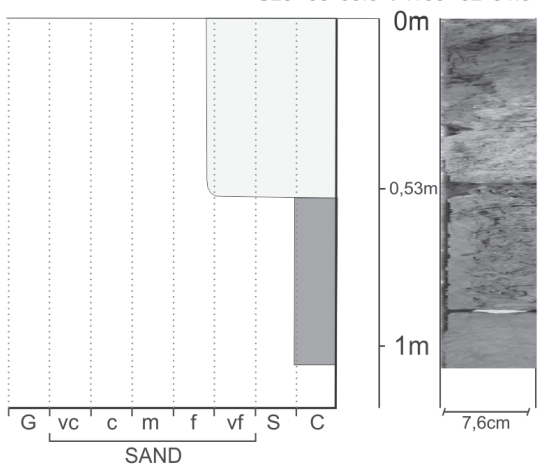

Figure 2. Sedimentological profiles of Coceira and Milharal ponds and Juriti alluvial fan.

2006). The abundant occurrence of $D$. pydanieli microscleras, Radiospongilla amazonensis gemoscleres and Metania spinata beta megascleres near the surface $(5 \mathrm{~cm})$ indicates a shallow pond with seasonal aridity less intense than between $40-10 \mathrm{~cm}$. $D$. pydanieli, $R$. amazonensis gemmoscleres and $M$. spinata beta megascleres near the surface suggest a shallow pond with abundant macrophytes vegetation with well-marked seasonal moisture and distinct dry intervals (Volkmer-Ribeiro et al., 1998).

Sponge spicules analysis from the Milharal pond deposits also can be characterized by essentially lacustrine environments. OSL (110-100 cm) and sponge spicule content indicates that pond formation occurred after 20,600 $\pm 4,800 \mathrm{yrs}$. Micropaleontological analysis suggests that this pond had been subject to environmental conditions drier than the those inferred for Coceira Pond. These drier conditions may be associated with the drier phase recognized on $40-10 \mathrm{~cm}$ range in the Coceira Pond core. A shallow pond with significant macrophytes is suggested by the abundant occurrence of Dosilia pydanieli and Radiospongilla amazonensis gemomoscleres and phytoliths between $20-0 \mathrm{~cm}$. The diatoms frustules on $10-0 \mathrm{~cm}$ interval

Table 1. Core 1 occurrence of sponge spicules and diatoms frustules. Abbreviations: $\varnothing$ absent; \pm very rare; + rare; ++ common; +++ abundant; Mb, beta Megascleres; G, Gemmoscleres; Mi, Microscleres; Fr, fragments; Wh, whole.

\begin{tabular}{|c|c|c|c|c|c|c|c|}
\hline \multirow{3}{*}{ Depth (cm) } & \multicolumn{6}{|c|}{ Freshwater sponges } & \multirow{3}{*}{ Unidentified frustules } \\
\hline & \multicolumn{2}{|c|}{$\begin{array}{l}\text { Unidentified } \\
\text { megascleres }\end{array}$} & \multicolumn{2}{|c|}{ D. pydanieli } & \multirow{2}{*}{$\begin{array}{c}\text { R. amazonensis } \\
\mathrm{G}\end{array}$} & \multirow{2}{*}{$\frac{\text { M. spinata }}{\mathrm{Mb}}$} & \\
\hline & $\mathrm{Fr}$ & $\mathrm{Wh}$ & G & $\mathrm{Mi}$ & & & \\
\hline 00 & \pm & \pm & + & \pm & + & + & \pm \\
\hline 05 & \pm & & + & +++ & + & \pm & \pm \\
\hline 10 & +++ & \pm & \pm & \pm & \pm & $\varnothing$ & $\varnothing$ \\
\hline 30 & +++ & \pm & \pm & $\varnothing$ & \pm & $\varnothing$ & \pm \\
\hline 40 & ++ & \pm & \pm & $\varnothing$ & $\varnothing$ & $\varnothing$ & $\varnothing$ \\
\hline 44 & \multicolumn{7}{|c|}{$26,900 \pm 5,000 \mathrm{yr}$} \\
\hline 55 & \pm & \pm & $\varnothing$ & $\varnothing$ & $\varnothing$ & $\varnothing$ & $\varnothing$ \\
\hline $120-60$ & $\varnothing$ & $\varnothing$ & $\varnothing$ & $\varnothing$ & $\varnothing$ & $\varnothing$ & $\varnothing$ \\
\hline
\end{tabular}


Table 2. Core 2 occurrence of sponge spicules, diatom frustules and phytoliths. Abbreviations: $\varnothing$ absent; \pm very rare; + rare; ++ common; +++ abundant; Mb, beta Megascleres; G, Gemmoscleres; Fr, fragments; Wh, whole.

\begin{tabular}{|c|c|c|c|c|c|c|}
\hline \multirow{3}{*}{ Depth (cm) } & \multicolumn{4}{|c|}{ Freshwater sponges } & \multirow{3}{*}{$\begin{array}{c}\text { Diatoms } \\
\text { Unidentified frustules }\end{array}$} & \multirow{3}{*}{ Phytoliths } \\
\hline & \multicolumn{2}{|c|}{ Unidentified megascleres } & \multirow{2}{*}{$\frac{\text { D. pydanieli }}{\mathrm{G}}$} & \multirow{2}{*}{$\begin{array}{c}\text { R. amazonensis } \\
\mathrm{G}\end{array}$} & & \\
\hline & $\mathrm{Fr}$ & $\mathrm{Wh}$ & & & & \\
\hline 00 & + & $\varnothing$ & \pm & \pm & +++ & + \\
\hline 05 & + & $\varnothing$ & \pm & \pm & +++ & + \\
\hline 10 & +++ & \pm & \pm & \pm & +++ & + \\
\hline 15 & + & $\varnothing$ & $\varnothing$ & $\varnothing$ & ++ & +++ \\
\hline 20 & + & $\varnothing$ & \pm & $\varnothing$ & $\varnothing$ & $\varnothing$ \\
\hline $100-30$ & $\varnothing$ & $\varnothing$ & $\varnothing$ & $\varnothing$ & $\varnothing$ & \pm \\
\hline $110-100$ & & & & $20,600 \pm 4,800 \mathrm{yr}$ & & \\
\hline $130-110$ & $\varnothing$ & $\varnothing$ & $\varnothing$ & $\varnothing$ & $\varnothing$ & \pm \\
\hline $165-130$ & $\varnothing$ & $\varnothing$ & $\varnothing$ & $\varnothing$ & $\varnothing$ & $\varnothing$ \\
\hline
\end{tabular}

Table 3. Core 3 occurrence of sponge spicules, diatom frustules and phytoliths. Abbreviations: $\varnothing$ absent; \pm very rare; + rare; M, Megascleres; G, Gemmoscleres; Fr, fragments.

\begin{tabular}{|c|c|c|c|c|c|}
\hline \multirow{3}{*}{ Depth $(\mathrm{cm})$} & \multicolumn{3}{|c|}{ Freshwater sponges } & \multirow{3}{*}{$\begin{array}{c}\text { Diatoms } \\
\text { Unidentified frustules }\end{array}$} & \multirow{3}{*}{ Phytoliths } \\
\hline & Unidentified megascleres & U. corallioides & T. repens & & \\
\hline & $\mathrm{Fr}$ & $\mathrm{G}$ & $\mathrm{M}$ & & \\
\hline 04 & \pm & $\varnothing$ & $\varnothing$ & \pm & + \\
\hline 14 & $\varnothing$ & $\varnothing$ & $\varnothing$ & $\varnothing$ & + \\
\hline 24 & \pm & $\varnothing$ & $\varnothing$ & $\varnothing$ & + \\
\hline 26 & \pm & \pm & \pm & $\varnothing$ & $\varnothing$ \\
\hline 30 & \pm & $\varnothing$ & $\varnothing$ & \pm & + \\
\hline 34 & $\varnothing$ & $\varnothing$ & $\varnothing$ & \pm & + \\
\hline 38 & + & \pm & \pm & $\varnothing$ & \pm \\
\hline 41 & \pm & $\varnothing$ & $\varnothing$ & $\varnothing$ & + \\
\hline 45 & + & $\varnothing$ & $\varnothing$ & $\varnothing$ & \pm \\
\hline 51 & \pm & $\varnothing$ & $\varnothing$ & $\varnothing$ & + \\
\hline 62 & \pm & $\varnothing$ & $\varnothing$ & $\varnothing$ & \pm \\
\hline $64-62$ & & 7,5 & & & \\
\hline $76-64$ & $\varnothing$ & $\varnothing$ & $\varnothing$ & $\varnothing$ & $\varnothing$ \\
\hline $97-78$ & $\varnothing$ & $\varnothing$ & $\varnothing$ & $\varnothing$ & \pm \\
\hline
\end{tabular}

Table 4. Core 4 occurrence of sponge spicules, diatom frustules and phytoliths. Abbreviations: $\varnothing$ absent; \pm very rare; + rare; ++ common; Fr, fragments.

\begin{tabular}{|c|c|c|c|}
\hline \multirow{3}{*}{ Depth $(\mathrm{cm})$} & Freshwater sponges & Diatoms & \multirow{3}{*}{ Phytoliths } \\
\hline & Potamolepidae family type & \multirow{2}{*}{ Unidentified frustules } & \\
\hline & $\mathrm{Fr}$ & & \\
\hline $10-0$ & $\varnothing$ & ++ & $\varnothing$ \\
\hline $20-10$ & \pm & $\varnothing$ & $\varnothing$ \\
\hline $40-30$ & $\varnothing$ & $\varnothing$ & $\varnothing$ \\
\hline $60-50$ & + & $\varnothing$ & \pm \\
\hline $107-70$ & $\varnothing$ & $\varnothing$ & $\varnothing$ \\
\hline
\end{tabular}

Table 5. Core 5 occurrence of sponge spicules, diatom frustules and phytoliths. Abbreviations: $\varnothing$ absent; \pm very rare; + rare; ++ common; $\mathrm{Fr}$, fragments.

\begin{tabular}{|c|c|c|c|}
\hline \multirow{3}{*}{ Depth $(\mathrm{cm})$} & Freshwater sponges & Diatoms & \multirow{3}{*}{ Phytoliths } \\
\hline & Potamolepidae family type & \multirow{2}{*}{ Unidentified frustules } & \\
\hline & $\mathrm{Fr}$ & & \\
\hline $10-0$ & $\varnothing$ & ++ & ++ \\
\hline 20 & ++ & $\varnothing$ & + \\
\hline 30 & \pm & $\varnothing$ & \pm \\
\hline 40 & + & $\varnothing$ & + \\
\hline 50 & + & $\varnothing$ & + \\
\hline 60 & + & $\varnothing$ & + \\
\hline $100-70$ & $\varnothing$ & $\varnothing$ & \pm \\
\hline
\end{tabular}



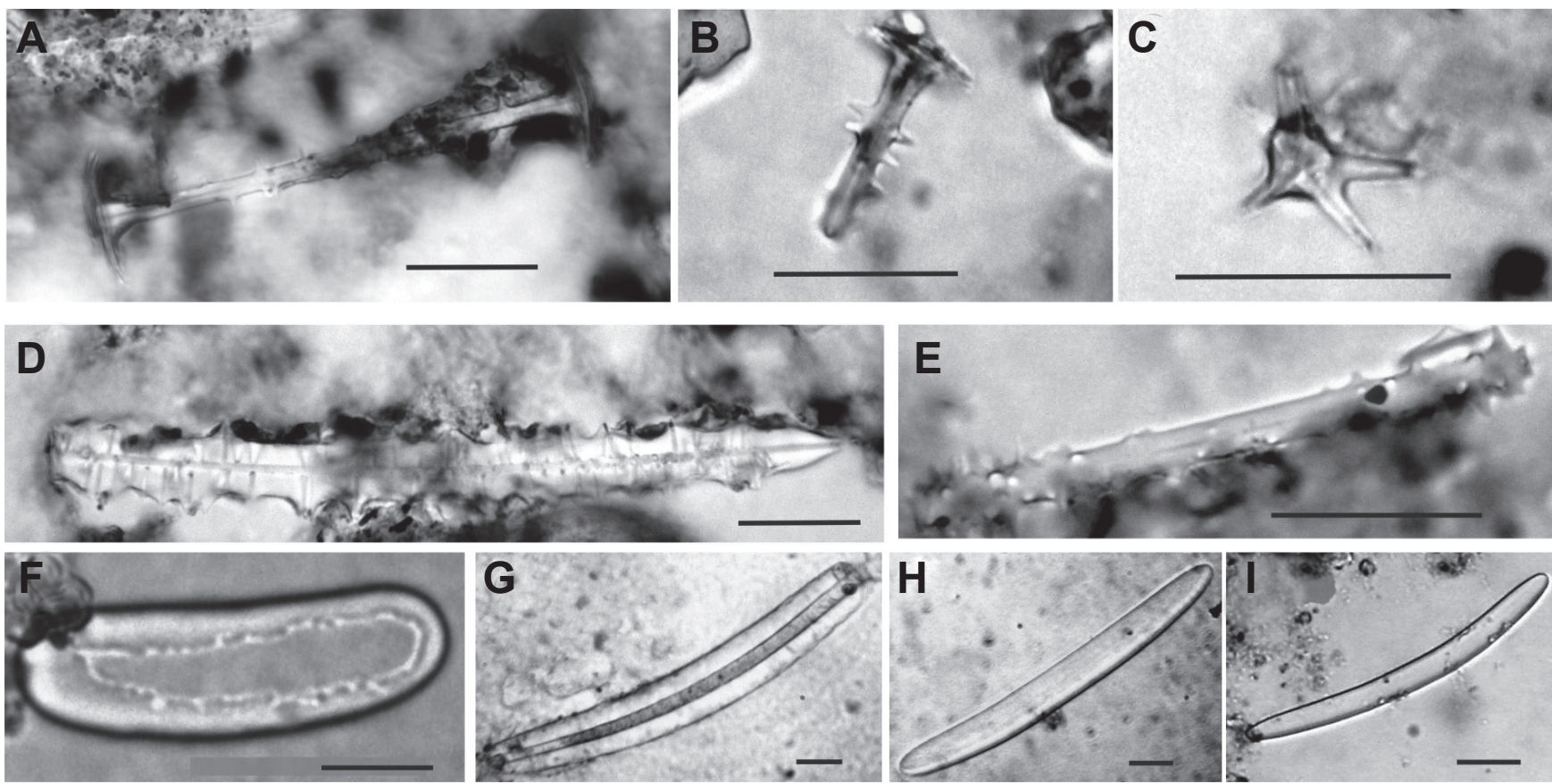

Figure 3. Freshwater sponges spicules. A-C, Dosilia pydanieli: A, gemmosclere; B, gemmosclere fragment; C, microsclere fragment. D, Metania spinata beta megasclere. E, Radiospongilla amazonensis gemmosclere. F-G, Uruguaya corallioides: F, gemmosclere; G, megasclere fragment. H-I, Trochospongilla repens megascleres. Scale bars $=25 \mu \mathrm{m}$.

can resulted from constantly wet environment with shallow water depth (Wolin \& Durthie, 1999), similar to the modern pond environment.

The sponge spicule analysis unequivocally shows that lotic environments did not contribute to the evolution of Coceira and Milharal ponds. Sponge species identified by the gemmoscleres Coceira and Milharal ponds are considered typical indicators of lacustrine environments of Cerrado biome (= Brazilian savanna) (Volkmer-Ribeiro, 1992, 1999; Volkmer-Ribeiro et al., 1998). Dosilia pydanieli, Radiospongilla amazonensis gemmoscleres and Metania spinata beta megascleres in sedimentary cores indicate environmental conditions similar to conditions found today in Central Brazil, with a well-defined dry season (winter) and lacustrine water level oscillations.

The results suggest the study area was covered by grasslands $(=$ campos $)$ or Brazilian savanna (= cerrado $)$ in the Late Pleistocene. This interpretation is consistent with dry climates in association with the prevalence of grasses in southeastern of Mato Grosso do Sul State ( $\sim 50 \mathrm{~km}$ north from the study area) from the Late Pleistocene to the Middle Holocene (Parolin et al., 2006). Similar vegetation and climatic conditions have also been recognized at Fazenda Pond, Middle Ivaí River, based on pollen records (Fernandes, 2008) and sponge spicules (Rezende, 2010) during the Late Pleistocene.

The lacustrine deposits (OSL 26,900 $\pm 5,000$ and OSL $20,600 \pm 4,800$ ) can be assigned to semi-arid climate phases (42,000 and 8,000 yrs BP) recognized in the Upper Paraná River by Stevaux (1993) and Stevaux \& Santos (1998).

\section{Alluvial fan}

Sedimentological and micropaleontological analyses from the Juriti fan cores characterized environmental conditions typical of alluvial fans in construction. The patterns of sponge spicules fragments (e.g. Uruguaya corallioides and Trochospongilla repens) in the cores can be linked to lotic environments, since these sponges have been recorded in lotic environments mainly in the Neotropical Region. During the construction of the Juriti fan dry climatic episodes with the development of grasses can be recognized by phytoliths intercalated with sponge spicules. The $\delta^{13} \mathrm{C}$ values $(-16,6 \%$ ) and phytoliths forms between $60-40 \mathrm{~cm}$ (Core 3, Table 3) corroborate this environment interpretation. This association may be formed under seasonally-flooded grassland environment with perennial marshes in its distal portion.

Wetter climate conditions with increased humidity and rainfall are dominant during the Early Holocene. Uruguaya corallioides gemmoscleres and Trochospongilla repens megaslceres identified in Core $3(38$ and $26 \mathrm{~cm}$ ) and flooding episodes at Juriti alluvial fan indicate wetter conditions at 7,540 years BP compared with the present. According to Batista et al. (2007), U. corallioides are most commonly found in rivers with turbulent flow. Diatoms frustules (30, 34 and 4 $\mathrm{cm}$ ) indicate that small swamps (= charcos) were established in the distal portion of the Juriti alluvial fan most likely due to flood pulses. The presence of ponds and small swamps are common in these environments (Assine, 2003)

This wetter period was interpreted by Guerreiro (2011) as a Holocene climatic optimum for the study area, relating the fan formation with paleoclimatic and paleoenvironmental transitional change of Late Pleistocene to the Holocene. Wetter phases were also identified by Stevaux (1993) and Stevaux \& Santos (1998) in Upper Paraná River between 8,000 and 6,500 yrs BP.

According to Guerreiro (2011), the first notable event of the climate transition in the study area was the increased humidity and precipitation, which was also recognized in the 
Upper Paraná River by Stevaux (1993, 1994), Stevaux et al. (1997), Stevaux \& Santos (1998) and Parolin (2006), but the phytogeographic change is the last to establish and develop.

Based on a study of phytoliths, Rasbold et al. (2010) found that the initial formation of Juriti fan vegetation was predominantly covered by grasses, possibly moving to forests only on Late Holocene. The lack of trees in the higher lands (sandstone rocks) and increased rainfall caused that small drainage sculpting valleys with $30 \mathrm{~m}$ average depth. The sediments materials were transported and deposited over the terraces in the Early Holocene.

\section{CONCLUSIONS}

Sponge spicules analysis from Milharal and Coceira Ponds sediments show that lotic processes were not involved in ponds genesis and evolution. The sponge spicules recorded mainly lacustrine environments since Late Pleistocene to the Holocene. Environmental conditions drier than today prevailed in the upper Paraná River on the Late Pleistocene

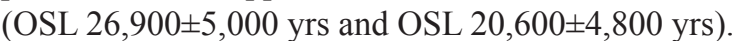

Sponge gemmoscleres taxa identified in these ponds are considered typical indicators from Brazilian savanna (= Cerrado biome) lacustrine environments, with a well defined dry season (winter), suggesting this type of environment in the Late Pleistocene. Wetter climate phases associated with higher humidity and precipitation in study area were only recognized in ${ }^{14} \mathrm{C} 7,540$ yrs BP with the alluvial fans formation.

\section{ACKNOWLEDGMENTS}

The authors would like to thank the Fundação Araucária (process 422/2009) for financial support; the National Council for Scientific and Technological Development - CNPq (processes 474559/2009-2 and 401765/2010-5) for financial support, the Master's scholarship to RLG and grants to JCS and MLA; the Lepafe/FECILCAM for laboratory facilities. To S. Kuerten, A. Silva, E. Souza Morais, P. França Junior and T. Dal Santo for field work support; to T. Matsushima for writing assistance; and to I. Ezcurra de Drago to confirm the identification of Uruguaya corallioides gemmoscleres and the identification of Trochospongilla repens megascleres.

\section{REFERENCES}

Assine, M.L. 2003. Sedimentação na Bacia do Pantanal Matogrossense, centro-oeste do Brasil. Programa de Pós-Graduação em Geologia, Universidade Estadual Paulista, Tese de LivreDocência, $106 \mathrm{p}$.

Batista, T.C.A.; Volkmer-Ribeiro, C. \& Melão, M.G. 2007. Espongofauna da Área de Proteção Ambiental Meandros do rio Araguaia (GO, MT, TO), Brasil, com descrição de Heteromeyenia cristalina (Porifera, Demospongiae). Revista Brasileira de Zoologia, 24:608-630.

Destefani, E.V. 2005. Regime hidrológico do rio Ivaí, PR. Programa de Pós-graduação em Geografia, Universidade Estadual de Maringá, M.Sc. thesis, 94 p.
Fernandes, R.S. 2008. Reconstrução paleoambiental da lagoa Fazenda durante o Pleistoceno tardio e região de Jussara, Estado do Paraná, com ênfase em estudos palinológicos. Programa de Pós-graduação em Análise Geoambiental, Universidade de Guarulhos, M.Sc. thesis, 125 p.

Ferreira, S.R. \& Caetano Chang, M.R. 2003. Morfologia quantitativa de lagoas, região de Taquaruçu (MS). Geografia, 28:241-259.

Ferreira, S.R. 1997. Caracterização geomorfológica e sedimentológica de lagoas associadas à calha do alto rio Paraná, região de Taquaruçu (MS). Instituto de Geociências e Ciências Exatas, Universidade Estadual Paulista, 141 p.

Fontana, A.C. 2009. A cobertura pedológica e as suas relações com a gênese das depressões no Terraço Taquarussu, MS, Brasil. Programa de Pós-graduação em Geografia, Universidade Estadual de Maringá, M.Sc. thesis, 118 p.

Guerreiro, R.L. 2011. Evolução geomorfológica e paleoambiental dos terraços da margem esquerda do alto rio Paraná. Programa de Pós-graduação em Geociências e Meio Ambiente, Universidade Estadual Paulista, M.Sc. thesis, 67 p.

Honaine, M.F.; Zucol, A.F. \& Osterrieth, M.L. 2006. Phytolith assemblages and systematic associations in grassland species of the South-Eastern Pampean Plains, Argentina. Annals of Botany, 98:1155-1165. doi:10.1093/aob/mcl207

Kuerten, S.; Parolin, M.; Assine, M.L. \& McGlue, M.M. 2013. Sponge spicules indicate Holocene environmental changes on the Nabileque River floodplain, southern Pantanal, Brazil. Journal of Paleolimnology, 49:171-183. doi:10.1007/s10933-012-9652-z

IAPAR - Instituto Agronômico do Paraná. 2012. Mapa climático. Available at http://www.iapar.br/modules/conteudo/conteudo. php? conteudo=597; accessed on 11/10/2012.

Leandrini, J.A.; Cavalcanti, A.V. \& Rodrigues, L. 2010. Diatomáceas In: M. Parolin; C. Volkmer-Ribeiro \& J.A. Leandrini (orgs.) Abordagem ambiental interdisciplinar em bacias hidrográficas no Estado do Paraná, Editora da FECILCAM, p. 131-155.

Lu, H.Y.; Wu, N.Q.; Liu, K.B.; Jiang, H. \& Liu, T.S. 2007. Phytoliths as quantitative indicators for the reconstruction of past environmental conditions in China II: palaeoenvironmental reconstruction in the loess plateau. Quaternary Science Reviews, 26:759-772. doi:10.1016/j.quascirev.2006.10.006

McGlue, M.M.; Silva, A.; Zani, H.; Corradini, F.A.; Parolin, M.; Abel, E.J.; Cohen, A.S.; Assine, M.L.; Ellis, G.S.; Trees, M.A.; Kuerten, S.; Gradella, F.S. \& Rasbold, G.G. 2012. Lacustrine records of Holocene flood pulse dynamics in the Upper Paraguay River watershed (Pantanal wetlands, Brazil). Quaternary Research, 78:285-294. doi:10.1016/j.yqres.2012.05.015

Osterrieth, M.; Madella, M.; Zurro, D. \& Alvarez, M.F. 2009. Taphonomical aspects of silica phytoliths in the loess sediments of the Argentinean pampas. Quaternary International, 193:7079. doi:10.1016/j.quaint.2007.09.002

Parolin, M. 2006. Paleoambientes e paleoclimas no final do Pleistoceno e no Holoceno no Sudeste do Estado do Mato Grosso do Sul. Programa de Pós-graduação em Ecologia de Ambientes Aquáticos Continentais, Universidade Estadual de Maringá, Ph.D. thesis, $121 \mathrm{p}$.

Parolin, M.; Medeanic, S. \& Stevaux, J.C. 2006. Registros palinológicos e mudanças ambientais durante o Holoceno de Taquarussu (MS). Revista Brasileira de Paleontologia, 9:137148.

Piperno, D.R. 2006. Phytolithis: a comprehensive guide for archaeologists and paleoecologists. $1^{\mathrm{a}}$ ed. AltaMira Press, Oxford, $238 \mathrm{p}$. 
Rasbold, G.G.; Guerreiro, R. L.; Parolin, M. \& Stevaux, J. C. 2010. Utilização de fitólitos em reconstrução paleoambiental do Holoceno tardio no noroeste do Estado do Paraná. In: REUNIÃO REGIONAL DE PALEONTOLOGIA DOS ESTADOS DO PARANÁ E SANTA CATARINA, 12, 2010. Resumos, Cascavel, UNIOESTE, p. 12.

Rezende, A.B. 2010. Espículas de esponjas em sedimentos de lagoa como indicador paleoambiental no NW do Estado do Paraná. Programa de Pós-graduação em Análise Geoambiental, Universidade de Guarulhos, M.Sc. thesis, 65 p.

Stevaux, J.C. 1993. O rio Paraná: geomorfogênese, sedimentologia e evolução quaternária de seu curso superior. Programa de Pós-graduação em Geologia Sedimentar, Universidade de São Paulo, Ph.D. thesis, $142 \mathrm{p}$.

Stevaux, J.C. 1994. Upper Paraná River (Brazil): geomorphology and paleoclimatology. Quaternary International, 21:143-161. doi:10.1016/1040-6182(94)90028-0

Stevaux, J.C. \& Santos. M.L. 1998. Palaeohydrological changes in the upper Parana River, Brazil, during the late Quaternary: a facies approach. In: G. Benito; V.R. Baker \& K.J. Gregory (eds.) Palaeohydrology and environmental change, John Wiley and Sons, p. 273-285.

Stevaux, J.C; Souza Filho, E.E. \& Jabur, I.C. 1997. A história quaternária do rio Paraná em seu alto curso. In: A.E.A.M. Vanzzoler; A.A. Agostinho \& N.S. Hahn (eds.) A planície de inundação do Alto Rio Paraná: aspectos fisicos, biológicos e socioeconômicos, Editora da Universidade Estadual de Maringá, p. 47-72.
Stoermer E.F. \& Smol J.P. 1999. The diatoms: applications for the environmental and earth sciences. Cambridge, Cambridge University Press, 469 p.

Volkmer-Ribeiro, C. 1992. The freshwater sponges in some peat-bog ponds in Brazil. Amazoniana, 12:317-335.

Volkmer-Ribeiro, C. 1999. Esponjas. In: D. Ismael; W.C. Valenti; T. Matsumuru-Tundisi \& O. Rocha (eds.) Biodiversidade do Estado de São Paulo: síntese do conhecimento ao final do século $X X$, 4: Invertebrados de água doce, FAPESP, p. 1-19.

Volkmer-Ribeiro, C.; Mansur, M.C.D.; Mera, P.A.S. \& Ross, S. M. 1998. Biological indicators in the aquatic habitats of the Ilha de Maracá. In: W.M.J. Ratter (ed.) Maracá: the biodiversity and environment of an Amazonian rainforest, John Wiley and Sons, p. 403-414.

Volkmer-Ribeiro, C. \& Parolin, M. 2010. As esponjas. In: M. Parolin; C. Volkmer-Ribeiro \& J.A. Leandrini (orgs.) Abordagem ambiental interdisciplinar em bacias hidrográficas no Estado do Paraná, Editora da FECILCAM, p. 105-130.

Volkmer-Ribeiro, C. \& Pauls, S.M. 2000. Esponjas de agua dulce (Porifera, Demospongiae) de Venezuela. Acta Biológica Venezuelica, 20:1-28.

Wolin, J.A. \& Duthie, H. 1999. Diatoms as indicators of water level change in freshwater lakes. In: E.F. Stoermer \& J.P. Smol (eds.) The diatoms: applications for the environmental and earth sciences, Cambridge University Press, p. 183-202.

Received in July, 2012; accepted in January, 2013. 